\title{
SIMULATED SOIL PROFILES AS A PLANT SCREENING TECHNIQUE
}

\author{
M.E. Wedderburn, W.J. Pengelly and M.A. Tucker \\ Whatawhata Research Centre, MAFTech, Hamilton
}

\begin{abstract}
A novel, simple technique for screening plants using simulated hill soil profiles is described.

Three large bins were constructed and a soil profile built up in each using layers of hill subsoil and topsoil compacted to field bulk density. 2100 ryegrass plants were transplanted at $5 \mathrm{~cm}$ spacing in each of the three bins.

This technique has enabled controlled manipulation of soil fertility, development of simulated pure sward conditions and identification of individual plants. It has been used successfully to screen the hill ryegrass collection held at Whatawhata Research Centre for response to nitrogen and drought.
\end{abstract}

Keywords: hill soils, ryegrass, nitrogen, drought, plant screening, soil profiles

\section{INTRODUCTION}

Pasture is in a state of flux, constantly subjected to various environmental pressures which vary in duration and magnitude. The two main environmental pressures acting on plants in hill country are soil fertility and moisture. The lack of nitrogen $(\mathrm{N})$ is generally the major factor limiting pasture production in hill country and the greatest response to application of $\mathrm{N}$ is from ryegrass (Sherlock \& O'Connor 1974; Ledgard et a/. 1983). Soil moisture decreases with increasing slope, owing predominantly to reduced opportunity for rainfall infiltration on steep compared with easy slopes (Gillingham 8 Bircham 1985). Aspect also affects moisture stress; soil moisture contents on south facing aspects are consistently higher than on north aspects (Gillingham \& Bircham 1985).

An opportunity to identify ryegrass genotypes which may be adapted to low fertility and drought stress is afforded by the hill ryegrass collection held at Whatawhata Research Centre. Included in the wide genetic base are nyegrass plants removed from properties with a history of low fertiliser application (e.g. Olsen $\mathrm{P}<7 ; \mathrm{C} / \mathrm{N}$ ratio $14: 1)$ and droughtprone strata, i.e. steep slopes $\left(>25^{\circ}\right)$, north aspects and from regions subject to seasonal drought (e.g. Wairarapa).

The cost and logistical difficulties of screening the 2000 plus genotypes of the ryegrass collection for variation in $\mathbf{N}$ and moisture stress tolerance precluded a general field screening over contrasting hill environments.

A large soil bin technique was developed to: (1) provide an environment which had a large soil volume similar to that of a hill soil profile, with close spacing of plants to impose competition effects; (2) measure responses to a number of environmental stresses over the whole hill country ryegrass collection and (3) use the technique for an initial screening of the variation in environmental stress tolerance within the collection and for identifying individual genotypes for further evaluation in the field.

\section{Soil bin construction}

\section{TECHNIQUES}

The bins were constructed from plywood and tanalised posts (details of materials and construction are documented in Tucker 8 Pengelly (1987)). The 
internal dimensions were $(7.85 \times 1.13 \mathrm{~m})$ and $0.6 \mathrm{~m}$ deep. Each bin was lined with a single piece of black agricultural plastic (about $10 \mathrm{~m}$ long) folded to produce a waterproof liner. Drainage holes were made $0.48 \mathrm{~m}$ below the bin surface and alternated along both sides of the bins.

\section{Sọil profile construction}

Soils were identified from hill country at the Whatawhata Research Centre. The rationale for choosing different soil types was based on acquiring a low $\mathrm{N}$ content topsoil and a moderate Al level in the subsoil. The topsoil was a Naike brown granular loam with the following soil properties: $\mathrm{pH}$ 5.0, $\mathrm{Ca} 4, \mathrm{~K} \mathrm{11}$, Olsen $\mathrm{P} 19, \mathrm{Mg}$ 17, phosphate retention 56, (Cornforth 1980), exchangeable Al 33 ppm. The Kaawa (yellow-brown earth) subsoil had an exchangeable Al level of $32 \mathrm{ppm}$.

Before removal of topsoil from the hill, the area was mowed, sprayed with paraquat and rotary hoed 2 days later. This reduced the vegetation content and clods were removed by raking the soil before placing in the bin.

Within the $60 \mathrm{~cm}$ bin depth the profile was built up in layers. The subsoil had a depth of $46 \mathrm{~cm}$ with the lower $31 \mathrm{~cm}$ being compacted unweighed soil. The remaining $15 \mathrm{~cm}$ of subsoil consisted of 3 layers each of $5 \mathrm{~cm}$ depth, each layer containing a weighed quantity of soil compacted to the correct depth. After each layer was compacted the surface was roughed up and loosened with rakes to prevent a pan forming. This was followed by a $5 \mathrm{~cm}$ layer of weighed compacted sub/topsoil mix and a $7 \mathrm{~cm}$ layer of weighed compacted topsoil. A $2 \mathrm{~cm}$ gap was left at the top of the bin to avoid soil spillage.

The profile was constructed to simulate the bulk density figures obtained from hill soils at Whatawhata, i.e. $0-5 \mathrm{~cm}, 0.67 \mathrm{~g} / \mathrm{cm}^{3} ; 5-30 \mathrm{~cm}, 1.06 \mathrm{~g} / \mathrm{cm}^{3}$ (Sheath \& Boom 1985). The quantity of soil required for each $5 \mathrm{~cm}$ layer was calculated using the bin volume, the moisture content of the soil and the required bulk density value.

The soil was weighed, added to the bin, raked out until there was an even cover and compacted down to the measured depth using a motorised plate compacter. After each layer was compacted, soil cores were removed to determine the actual bulk density (Table 1). The subsoil bulk densities were close to those required, whereas the values for the topsoil layer were higher than expected. Both inorganic $\mathbf{N}$ and mineralised $\mathbf{N}$ were measured on cores removed from the topsoil in each bin (Table 2). Bin 1 was filled first and the higher nitrate and lower ammonium levels

Table 1: Bulk density values $\left(\mathrm{g} / \mathrm{cm}^{3}\right)$ for each layer in the soil profile of three bins.

\begin{tabular}{lccc}
\multicolumn{1}{c}{$\begin{array}{c}\text { Soil } \\
\text { layer }\end{array}$} & 1 & Bin Number & \\
\hline $0-75 \mathrm{~cm}$ & 1.20 & 2 & 3 \\
$12-22 \mathrm{~cm}$ & 1.06 & 1.20 & 1.20 \\
$23-37 \mathrm{~cm}$ & 1.08 & 1.16 & 1.16 \\
\hline
\end{tabular}

Table 2: Inorganic $\mathbf{N}, \mu \mathrm{N} / \mathrm{g}$ oven dried soil), mineralised $\mathrm{N}$ and $\mathrm{N}$ present in bins at tiller planting. Measurements were from $7 \mathrm{~cm}$ soil, cores removed from each of three bins after completion of soil profile

\begin{tabular}{cccc}
\hline & \multicolumn{2}{c}{ Inorganic $\mathrm{N}$} & $\begin{array}{c}\text { N present in bin } \\
\text { at planting kg N/ha/7 cm } \\
\text { depth }\end{array}$ \\
\hline Bin & $\mathrm{NH}_{4}$ & $\mathrm{NO}_{3}$ & 63.7 \\
2 & 13.7 & 62.1 & 56.6 \\
$\mathrm{~B}$ & 19.6 & 47.8 & 61.0 \\
\hline
\end{tabular}


therein were due to the earlier initiation of enhanced mineralisation after soil disturbance. All bins showed similar levels of inorganic $\mathrm{N}$ in soil at planting (Table 2) which was high enough for rapid initial plant growth.

\section{Planting}

Each bin was subdivided into 30 equal blocks and paraquat and dacthal $75 \mathrm{~W}$ were applied to prevent weed and grass germination. Seventy tillers were transplanted into each block, 7 rows of 10 plants. Frames were used to define the lines and space the plants. Plants were spaced on a $5 \mathrm{~cm}$ hexagonal pattern, which produced a $5 \mathrm{~cm}$ space between an individual and its 6 neighbouring plants, and used the soil area most efficiently. Two tillers per plant were transplanted.

Rows $1,3,5$ and 7 included a cloned plant as the 10th plant, and a central row of a single cloned plant at $5 \mathrm{~cm}$ spacings was included to act as a check on local variability within the bin and for use as a covariate in analysis. Four rows of guard plants were transplanted around the edge of each bin. Each bin had exactly the same layout and the plants were cloned across all three.

A total of 2100 genotypes were transplanted into each bin, including 1800 from the hill country ryegrass collection, 180 cultivars and 120 cloned plants.

\section{Screening treatments}

The technique was used to screen the hill country ryegrass collection for response to $\mathrm{N}$ and moisture stress.

\section{Nitrogen stress}

The $\mathrm{N}$ source used was a $1\left(\mathrm{NH}_{4} \mathrm{NO}_{3}\right): 2\left(\mathrm{CaNO}_{3}\right)$ mix at a rate equivalent to $7 \mathrm{~kg}$ $\mathrm{N} /$ ha/week This supplied an adequate regular supply of $\mathrm{N}$. In a good growing pasture the vegetation will utilise around $1 \mathrm{~kg} \mathrm{~N} /$ day, slightly higher in the spring (Ledgard pers. comm.). It was applied once a week in solution using a boom sprayer which travelled along a fixed rail to ensure even coverage. One bin received $\mathrm{N}$ and the remaining two received an equivalent amount of water. The experiment began in June and individual plants were harvested in July, September and October. The objective was to identify the following four types of responses from the plants:

1. The most productive 15 genotypes growing with $\mathrm{N}$

2. The most productive 15 genotypes growing without $\mathrm{N}$

3. 15 genotypes with the least response to $\mathrm{N}$ and expressed as the relative difference between growth under low and high $\mathrm{N}$

4. 15 genotypes with the greatest response to $\mathrm{N}$ measured as the relative difference between growth under low and high $\mathrm{N}$

At each harvest, production from $90 \%$ of plants in the no- $\mathrm{N}$ bins was $0-0.3 \mathrm{~g}$ dry matter. Only $4 \%$ of genotypes yielded $>0.4 \mathrm{~g}$. In the bin receiving $\mathrm{N}, 69 \%$ of genotypes yielded $0-0.3 \mathrm{~g}$, while $19 \%$ yielded in excess of $>0.4 \mathrm{~g}$. Plants were ranked in order of dry matter and these rankings remained similar between the two no-N bins and for each harvest.

\section{Moisture stress}

The bins were modified to accommodate the drought trial. Gypsum blocks were inserted at various depths and positions within each bin to allow monitoring of soil moisture status. They were readusing CR 21 data loggers and converted using a calibration curve to express soil moisture as bars.

A rain shelter was constructed over two bins. Wooden supports similar to the bin height were built $0.5 \mathrm{~m}$ out and parallel to the bins. PVC pressure pipe was bent and inserted into the supports to produce a frame one metre above the bin surface. Clear plastic was drawn over the frame and anchored down; the plastic could be easily removed. Shade cloth could also be drawn over the plastic cover when required. 
Water was withheld from one sheltered bin and the second received water based on readings from the gypsum blocks, in order to maintain growth. Because of the large soil volume in each bin, there was a natural drying down and hardening of without the need to put the plants through a cycle of wetting and drying which is documented for some pot or pipe experiments (Norris 8 Thomas 1982).

At the first sign of wilting, scoring began on a scale of 1.5 (1 apparently dead, i.e. leaves all brown, 2 green tinge to the leaves, 3 leaves half brown half green limp, 4 green leaves but wilted, 5 healthy, i.e. leaves green and turgid). At the end of 12 weeks without water and 5 weeks in excess of -12 bars (drier than "wilting point") all plants were scored as 1 . A cumulative score was calculated, i.e. those plants with a high cumulative score took longer to reach a score of 1 . At this point, water was added over a period of 2 days until the bin reached field capacity.

There was only $21 \%$ kill during the period of moisture stress. After the plants recovered tillers were scored on a scale of $0-4(0=$ dead, $4=100 \%$ tiller survival $)$. Eleven percent of plants had lost $75 \%$ of their tillers during the period, $19 \%$ lost $50 \%$ of their tillers, $33 \%$ lost $25 \%$ of their tillers and $16 \%$ lost none.

This particular moisture stress was therefore insufficient to eliminate a high percentage of plants. It is proposed to run similar drought trials using the bins and superimposing a cut during the trial in an effort to identify plants which can survive and recover from this dual stress.

\section{CONCLUSIONS}

This technique is a means of screening a large number of genotypes before field evaluation starts.

The bins reduce environmental variation and provide a uniform and known soil profile.

Any type of treatment can be superimposed over the plants and individual responses can be measured. Both shoot and root responses could be measured by removing cores from the profile.

In this ryegrass study a pure sward was developed but once plants were accurately placed and readily identified other species could be oversown to form a mixed sward.

The bins could be re-used by removing the topsoil layer and substituting other soils.

\section{References}

Cornforth, I.S. 1980. Aglink AST 8, Soils and Fertilizers Soil Analysis. Aglink MAF Wellington.

Gillingham, A.G.; Bircham, J.S. 1985. Soil moisture monitoring and modelling $\mathrm{cm}$ steep hill country. In I.B. Cambell (Ed) Proceedings of a seminar on soil dynamics and land use. Blenheim, May.

Ledgard. S.F.; Brier, G.J.; Gillingham. AG.; Sheath, G.W. 1983. Influence of some soil and pasture components on the growth of hill country pastures II. Response to nitrogen fertiliser. NZ journal of experimental agriculture 11: 251-56.

Norriss, I.B.; Thomas, H. 1982. The effect Of droughting on varieties and ecolypes of Lolium, Dactylis and Festuca. Journal of applied ecology 19: 681-69.

Sheath, G.W.; Boom, R.C. 1985. Effects of November - April grazing pressure on hill country pastures 3. Interrelationship with soil and pasture variation. NZ journal of experimental agriculture 13: 341-49.

Sherlock. R.R.; O'Connor, M.B. 1974. The use of nitrogen on hill country. Proceedings NZ Grassland Association 35: $52-62$.

Tucker, M.A: Pengelly, W.J. 1987. Techniques used to describe ryegrass. Technical Report No. 1, July. Whatawhata Hill Country Research Station. 